\title{
Sprout density for the production of organic mini-cabbage from mother plant regrowth
}

\author{
Jacimar Luis de Souza ${ }^{1^{*}}$ Rogério Carvalho Guarçoni ${ }^{1}$ Luiz Fernando Favarato ${ }^{1}$ \\ Maria da Penha Angeletti ${ }^{1}$ Douglas Vianna Bahiense ${ }^{1}$ Camila de Souza Ribeiro ${ }^{2}$
}

${ }^{1}$ Centro Regional de Desenvolvimento rural (CRDR), Centro Serrano (CS), Instituto Capixaba de Pesquisa, Assistência Técnica e Extensão Rural (Incaper), BR-262, km 94, 29180-000, Domingos Martins, ES, Brasil. E-mail: jacimarsouza@yahoo.com.br. "Corresponding author. ${ }^{2}$ Profissinal autônomo, Campos dos Goytacazes, RJ, Brasil.

\begin{abstract}
The method of producing organic mini-cabbages from regrowth of mother-plant was initiated at the Unidade de Referencia em Agroecologia of the Incaper in 2013, possibly acting as an efficient alternative for the obtainment of cabbages with a more adequate average weight for the desires of the modern consumer. The aim of this study was to define sprout density in the mother plant, which allows better productivity and commercial standards for organic mini-cabbages. The experiment was developed during the period from September to November 2015, using the $F$, Shinsei hybrid, in a design with randomized blocks, with five replications. Sprout density was determined following thinning, constituting the following treatments: two, three, four, five and six sprouts per plant. Best management of sprouts

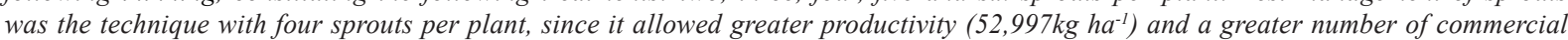
heads, together with a commercial standard of heads with average weight (414g) and median diameter (8.8cm) adequate for the standards demanded by the consumer.
\end{abstract}

Key words: Brassica oleracea, var. capitata, organic cultivation, mini-vegetables, plant density.

Densidade de brotos para a produção de mini-repolho orgânico do rebrota da planta mãe

RESUMO: A técnica de produção de mini-repolhos orgânicos por rebrota da planta-mãe foi iniciada na Unidade de Referência em Agroecologia do Incaper, no ano de 2013, podendo ser uma alternativa eficiente para obtenção de repolhos com peso médio mais apropriado ao desejo do consumidor moderno. O objetivo deste trabalho foi definir a densidade de brotos da planta-mãe, que permita melhor produtividade e padrão comercial de mini-repolhos orgânicos. O experimento foi desenvolvido no período de setembro a novembro de 2015, utilizando-se o hibrido $F_{I}$ Shinsei, no delineamento de blocos casualizados, com cinco repetições. As densidades de brotos foram estabelecidas após desbastes, constituindo os seguintes tratamentos: dois, três, quatro, cinco e seis brotos por planta. O melhor manejo de rebrotas foi a condução com quatro brotos por planta, pois permitiu maior produtividade (52.997kg ha ${ }^{-1}$ ) e maior número de cabeças comerciais, aliados a um padrão comercial de cabeças com peso médio (414g) e diâmetro médio (8,8cm) adequados aos padrões exigidos pelo consumidor.

Palavras-chave: Brassica oleracea, var. capitata, cultivo orgânico, mini-hortaliças, densidade de plantas.

\section{INTRODUCTION}

At the beginning of the 1990's, the miniature vegetable market experienced a more consistent evolution in developed countries in Europe, undergoing changes to consumer preferences, especially in terms of valorization of these products in gourmet kitchens and fast food chains. According to BACHMANN (2002), demand grew rapidly and created one of the greatest expansions in the 'specialty crop' market in the United States, as well as influencing agriculture, consumption patterns and vegetable markets in countries such as Brazil. Initially, only the owners of the most refined restaurants used these products in their dishes, but starting from 2000, these differentiated vegetables began to be found in retail and wholesale markets (ECHER et al., 2014). 
ROSARO et al. (2013) reported that the increased demand for mini-vegetables is related to tendencies in the consumption of foods beneficial for health, with better flavor and ease of preparation for consumption, together with ecological questions, related to the habits of modern consumers. AQUINO et al. (2005) also reported that due to the lower number of members of Brazilian families and the greater degree of knowledge regarding quality of products, current consumers have given preference to smaller sized products, where possible, associated with greater nutritional value.

Mini-vegetables commonly reported in super markets are tomatoes, carrots, beetroot, mini-corn, peas, beans, lettuce, onions, cauliflower, eggplant, potatoes and pumpkin. The reduced size can be obtained by using genetically improved cultivars, by management of cultivation, through earlier harvesting or through post-harvest processing for size reduction. For the cherry tomato and the mini-potato, naturally small cultivars are used. For carrot, an improved cultivar exists for mini-size or through postharvesting processing for the reduction of size. For corn, mini-corn is obtained through the use of a cultivar selected for this purpose or through higher density planting and earlier harvesting (BACHMANN, 2002).

One of the great advantages for the production of mini-vegetables is the elevated added value and the small price variation on the market. In 2013, the median annual price of a kilo of cherry tomatoes was R\$3.98, $152 \%$ greater than the R\$ 1.58 for long life tomatoes (CEASA-ES, 2014). This valorization is below that some reports given by SABIO, VENTURA \& CAMPOLI (2013), who indicated higher values for mini-vegetables, such as $364 \%$ for watermelon, $394 \%$ for tomatoes, $848 \%$ for onions, $927 \%$ for cucumber and $1384 \%$ for carrots.

Numerous studies have reported that the size of the commercial product to be obtained can be altered through increasing planting density and by interfering in competition for water, light and nutrients (LOPES et al., 2008; CARVALHO et al., 2010; BEZERRA et al., 2014). For the family of crucifers especially the culture of cabbage, numerous spacing combinations and planting densities are used, depending on cultivar, soil type, fertilization and desired commercial standard amongst other factors (FERREIRA et al., 2014). In the cultivation of mini-watermelons, it was reported that an increase in stem density led to a commensurate increase of fruit production, but reduced median size by $12.5 \%$ (CAMPAGNOL et al., 2016).

TAKAHASHI \& CARDOSO (2014), evaluating density of mini-lettuce cultivars in organic systems, showed that the average weight was greater with wider spacing of $0.25 \times 0.20 \mathrm{~m}$, but that the mass of fresh material of the plants and the commercial productivity were greater with the closer spacing of $0.15 \times 0.15 \mathrm{~m}$.

In the production of mini-cabbages, the two available alternatives for the production of heads of a smaller size are the use of commercial hybrids and the reduction of spacing for planting. Amongst mini-cabbage hybrids, 'Nozomi', 'Yakko' and 'Gonzales' stand out for allowing the production of heads of 0.8 to $1.0 \mathrm{~kg}$, a size which is still considered excessive to satisfy baby vegetable standards. The alternative of reducing the spacing for planting reduces the average weight of the heads (SILVA, et al., 2011), but in a manner insufficient to obtain mini-cabbages. The option for the cultivation of secondary sprouts originating from the regrowth of adult plants after cutting/harvesting of the single head, was reported by COOLONG (2013), for the cultivation of broccoli, which permits harvesting at a reduced size. There are no reports in the literature regarding the alternative of producing mini-cabbages through the cultivation of secondary sprouts.

The production technique of organic mini-cabbages through sprout from the mother-plant was initiated at the Unidade de Referência em Agroecologia of the Incaper, municipality of Domingos Martins/ES, in 2013, being a potentially efficient alternative for the obtainment of cabbages of medium weight more adequate for the desires of the modern consumer. Continuing this process of technological innovation, the aim of this study was to define sprout density on the mother plant, to permit a better production and commercial standard of organic mini-cabbages.

\section{MATERIALS AND METHODS}

The study was realized at the Fazenda Experimental Mendes da Fonseca at the Instituto Capixaba de Pesquisa, Assistência Técnica e Extensão Rural. The site is located in the municipality of Domingo Martins (ES), with the geographic coordinates $20^{\circ} 22^{\circ} 17^{\prime} \mathrm{S}$ and 
$41^{\circ} 03^{\text {ec }} 40$ "O, at an altitude of $950 \mathrm{~m}$. The climate is characterized as rainy tropical with a dry winter and rainy summer, with an Aw classification, according to Köppen. The average temperature of the maximums is situated between $26.7^{\circ} \mathrm{C}$ and $27.8^{\circ} \mathrm{C}$ and the average of the minimums between $8.5^{\circ} \mathrm{C}$ and $9.4^{\circ} \mathrm{C}$.

The experiment was developed during the period of September and November 2015, in the area of the Unidade de Referência em Agroecologia of the Incaper, a production system under organic management since 1990, in a soil unit with the classification of sandy clay. At a depth of $0-20 \mathrm{~cm}$, this soil shows the following chemical characterization, according to the EMBRAPA (1997) and YEOMANS \& BREMNER (1988): $\mathrm{pH}$ in water (6.5); organic material (2.8dag $\left.\mathrm{kg}^{-1}\right)$; phosphorous $\left(235 \mathrm{mg} \mathrm{dm} \mathrm{dm}^{-3}\right)$; potassium $\left(75 \mathrm{mg} \mathrm{dm}^{-3}\right)$; calcium $\left(7.9 \mathrm{cmol}^{\mathrm{d}} \mathrm{dm}^{-3}\right)$; magnesium $\left(1.3 \mathrm{cmol}_{\mathrm{c}} \mathrm{dm}^{-3}\right)$; sum of bases $\left(9.5 \mathrm{cmol}_{\mathrm{c}}\right.$ $\left.\mathrm{dm}^{-3}\right) ; \mathrm{H}+\mathrm{Al}\left(2.1 \mathrm{cmol} \mathrm{dm}^{-3}\right) ; \mathrm{Al}^{+3}\left(0.0 \mathrm{cmol} \mathrm{dm}^{-3}\right)$; capacity of potential cationic exchange $\left(11.6 \mathrm{cmol}_{\mathrm{c}}\right.$ $\left.\mathrm{dm}^{-3}\right)$ and saturation by bases $(81.9 \%)$.

To assess mini-cabbage production by sprout, starting from the number of sprouts per plant, a primary cabbage patch was sown on April 16, 2015 and transplanted on May 26, 2015, employing the spacing of $0.60 \times 0.40 \mathrm{~m}$, which is the most commonly recommended and equivalent to a population of 41, 667 plants per hectare. The F1 Shinsei hybrid was used, which has the potential to produce heads with a median weight of $2.19 \mathrm{~kg}$ and an average diameter of $19.0 \mathrm{~cm}$ in conditions of the Rio Grande do Sul, as reported by FRACARO et al. (1999).

Fertilizing of the primary patch was done with organic compost in the planting hole, with a base of $30 \mathrm{t} \mathrm{ha}^{-1}(720 \mathrm{~g}$ per plant), watering by hose before transplanting the seedlings was used. Average chemical characterization of the compound utilized was: MO (48\%), C/N (13/1), $\mathrm{pH}(7.4)$ and $2.0 ; 1.2 ; 1.5 ; 6.0 ; 0.6 \mathrm{dag} \mathrm{kg}^{-1}$ of $\mathrm{N}, \mathrm{P}, \mathrm{K}, \mathrm{Ca}$ and $\mathrm{Mg}$, respectively. In the field for the production of mini-cabbages from sprout, only one covering of fertilizer with a base of $10 \mathrm{t} \mathrm{ha} \mathrm{ha}^{-1}(240 \mathrm{~g}$ per plant) was realized. In the management of the experimental patch, three manual weeding were carried out to control spontaneous weeds, with periodic irrigations of around three days of watering during times of drought. As an alternative method for pathogen control, an application of bordelloa syrup after initial harvesting was used, seeking to prevent bacteria in the region of the cut of the heads.
After establishment of the sprouts, old leaves were removed from the previous cultivation, seeking to prevent diseases.

The primary patch for cabbage production was harvested on September 01, 2015, totaling a cycle of 136 days. The median productivity was $83,300 \mathrm{~kg} \mathrm{ha}^{-1}$, the median weight of the heads was 2009 grams, the median diameter of the heads was $20.9 \mathrm{~cm}$ and the compactness of the heads was 9.8. The mini-cabbage experiment was implanted on September 09, 2015, after harvesting from the primary patch. Number of secondary sprouts on each stalk was controlled by removal, realized 38 days after the implantation of the experiment (October 09, 2015), leaving the number of sprouts according to each treatment.

The experimental design was established using randomized blocks, with 5 repetitions. The parcels were composed of 7 plants regrown in the total area $\left(1.68 \mathrm{~m}^{2}\right)$ and five plants in the useful area $\left(1.2 \mathrm{~m}^{2}\right)$. Density of sprouts per plant was established after thinning, realized according to the following treatments: two, three, four, five and six sprouts.

Commercial classification adopted for mini-cabbages was determined by the transversal diameter of each head equal to or superior to six $\mathrm{cm}$. Total productivity was evaluated, obtained by the weight of all the heads in the useful area of the parcel, weighed on a digital scale and transformed for one hectare. Number of commercial heads was obtained via the count of total heads of the useful area of the parcel. Commercial productivity was obtained via the weight of the commercial heads in the useful area of the parcel, which presented a diameter equal to or greater than $6.0 \mathrm{~cm}$ weighed on digital scales and transformed for one hectare). Percentage of weight of commercial heads (obtained from the relationship between the commercial weight and the total weight of the heads of the parcel. Median weight, obtained from the relationship between the weight and the number of commercial heads per parcel) and median diameter, obtained from the median of the diameter of head of a sample of five mini-cabbages from each parcel, weighed with a digital pachymeter.

The firmness of the heads was determined by the index of compactness, on a scale from 1 to 10 , obtained from the average of the scores of a sample of five mini-cabbages from each parcel. A score of 0 (zero) is unusual due to its corresponding to a head with completely limp leaves where there is no 
resistance to pressure from touch, being classified as non-commercial. For the scores obtained from this scale typically adopted in research with this cultivation, the evaluator was trained to apply a standard pressure with thumbs on the center of the head of the cabbage, defining the values according to depth that the finger of the evaluator reaches in the direction of the center of the head. A score of 1 (one) indicates the penetration of the finger to $3.0 \mathrm{~cm}$ or more and 10 (ten) when the head presents total firmness to touch, giving at the most $0.1 \mathrm{~cm}$. The intermediary values are established according to the following depths: from 2.9 to $2.5 \mathrm{~cm}$ (score 2); from 2.4 to $2.0 \mathrm{~cm}$ (score 3); from 1.9 to $1.5 \mathrm{~cm}$ (score 4 ); from 1.4 to $1.0 \mathrm{~cm}$ (score 5); from 0.9 to $0.7 \mathrm{~cm}$ (score 6); from 0.6 to $0.5 \mathrm{~cm}$ (score 7 ), from 0.5 to $0.4 \mathrm{~cm}$ (score 8); from 0.3 to $0.2 \mathrm{~cm}$ (score 9).

The data for number of heads, percentage of weight of commercial heads and compactness of heads of mini-cabbages were transformed, by the functions $y=\sqrt{x}, y=\operatorname{arcsen}[\sqrt{(x / 100)}]$ and $y=\sqrt{x}$, respectively, due to the lack of normality and homogeneity of the variations, utilizing the Lillifors and Cochram $\&$ Bartlett tests. The treatments were considered qualitative due to there not existing a continuity for the variable 'number of sprouts per plant', with its averages compared by the Scott Knott test at $\mathrm{P}>0.05$ probability of error.

\section{RESULTS AND DISCUSSION}

The harvesting of mini-cabbages was done in a staggered manner, starting on Nov. 11, 2015 and ending on Dec. 11, 2015, to the extent that the mini-cabbage heads reached the minimum necessary compactness. The median date of harvesting on the Nov. 26, 2015, gave an average cycle of 86 days starting from the primary harvesting of 48 days after thinning of sprouts. The average cycle for the production of mini-cabbages was 50 days earlier than primary production, which had a cycle of 136 days. This data corroborates with BEALE (2013), who reported the shorter timeframe from planting to harvesting as being a great advantage of mini-vegetables.

Figure 1 illustrates some steps in the production process of mini-cabbages from regrowth, especially showing post-harvest preparation practices and packaging of the product. Total productivity was greater for the group made up of treatments with four sprouts or more per plant, in relation to the others (Table 1). After the commercial classification, it was reported that the best agronomical option is the management of sprouts for cultivation with four sprouts per plant, which stood out from the other treatments. This result was due to the greater proportion of sprouts classified as commercial in each plant for this treatment, in other words, on average 3.1 sprouts of the four on each plant (the other treatments produced 2, 2.6, 2.4 and 2.9 commercial sprouts on average, respectively, for plants with two, three, five and six sprouts).

The control of apical dominance mediated by auxin, which moves from the tip of the branches (one of the main locations of synthesis) in the direction of the lateral sprouts exercises an inhibitory function (TAIZ \& ZAIGER, 2017). In this way, when the harvesting of the main head of the cabbage plant is carried out, there is a breaking of apical dominance and a stimulation of the lateral sprouts, which grow in an alternating manner. With this alternating growth, the upper sprouts develop more rapidly than the lower sprouts on the stem, becoming a greater drain on the limited source of products assimilated by the plant, as well as exercising an inhibitory effect on the growth of the adjacent sprouts, stimulated by the auxin produced by the apical meristem (TAIZ \& ZAIGER, 2017). Therefore, the cabbage plants presented a maximum support of 3.1 commercial sprouts per plant, obtained in the treatment where the plants were grown with four sprouts.

The most significant commercial productivity of approximately $52 \mathrm{t} \mathrm{ha}^{-1}$ obtained with four sprouts per plant (Table 1), was greater than that obtained by BON (2005), who reported median productivity of mini-cabbage of 14.9 and $10.5 \mathrm{tha}^{-1}$, in closed cultivation and open patch, respectively, working with a commercial variety of mini-cabbage. This data confirmed the great agronomical and technological viability of the management technique presented.

Plants grown with two sprouts had an index of $100 \%$ of the weight of commercial mini-cabbages, while those with three and four sprouts showed a reduction to $93.2 \%$ and $90.5 \%$, respectively. Treatments with five and six sprouts compromised commercial production, dropping to $76.1 \%$ and $73.9 \%$, respectively (Table 1 ). In the treatment with only two sprouts per plant there was lower competition of photoassimilates, allowing the adequate growth of heads to attain minimum commercial standard of $0.6 \mathrm{~cm}$ of diameter. Beginning from three sprouts per plant the competition for water and nutrients limits the growth of the heads, reducing the percentage of commercial heads. 

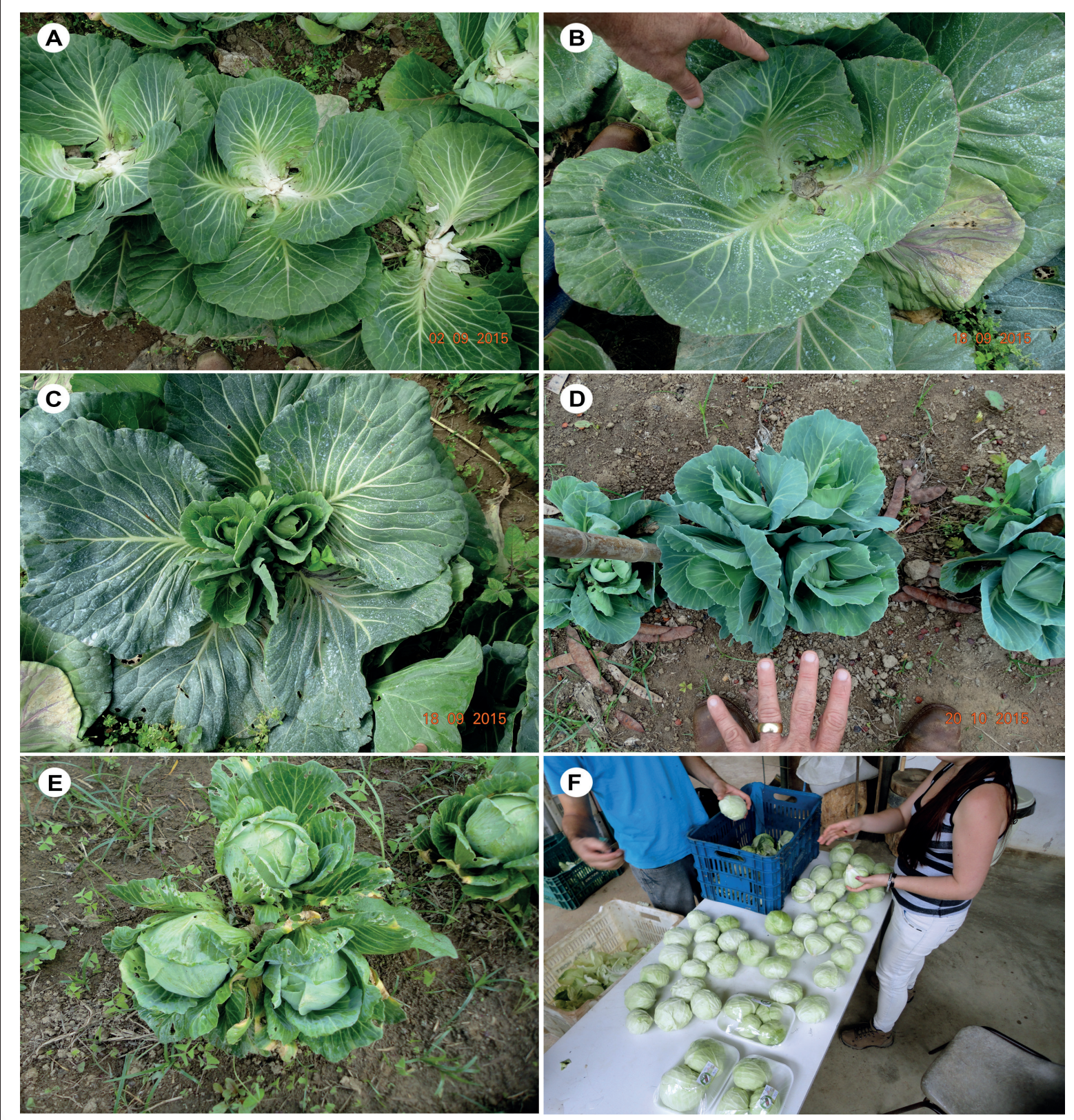

Figure 1 - Mother-plant of cabbage soon after harvesting the head in the primary patch (A); phytosanitary treatment at the start of regrowth (B); sprouts in intermediary stage (C); plants grown with four sprouts, after removal of old leaves (D); plants grown with three sprouts, during harvest phase (E); preparation and packaging of organic mini-cabbages (F). Domingo Martins, INCAPER, 2016.

Observing commercial quality standards, expressed in terms of average weight, average diameter and compactness of heads (Table 2), it was seen that the fewer the sprouts per plant, the greater the average weight obtained, resulting from the lower competition for photoassimilates, similar to the results of TAKAHASHI \& CARDOSO (2014) for mini-lettuce. Treatments can be grouped into three distinct groups: greater average weight with two sprouts per plant, intermediary average weight with treatment of three to five sprouts per plant and lower average weight with six sprouts

Ciência Rural, v.47, n.9, 2017. 
Table 1 - Average of total productivity characteristics, number of commercial heads per hectare, commercial productivity and percentage of weight of commercial mini-cabbage heads. Domingos Martins, INCAPER, 2016. ${ }^{1}$

\begin{tabular}{|c|c|c|c|c|c|c|c|c|}
\hline \multirow{2}{*}{$\begin{array}{l}\text { Density of sprouts per plant } \\
\text { Two }\end{array}$} & \multicolumn{2}{|c|}{$\begin{array}{l}\text { Total productivity } \\
\qquad\left(\mathrm{kg} \mathrm{ha}^{-1}\right)\end{array}$} & \multicolumn{2}{|c|}{$\begin{array}{l}\text { Number of commercial } \\
\text { heads per ha }\end{array}$} & \multicolumn{2}{|c|}{$\begin{array}{l}\text { Commercial productivity } \\
\qquad\left(\mathrm{kg} \mathrm{ha}^{-1}\right)\end{array}$} & \multicolumn{2}{|c|}{$\begin{array}{l}\text { Percentage of weight of } \\
\text { commercial heads }^{3}\end{array}$} \\
\hline & $42,416.67$ & $\mathrm{c}$ & $83,336.14$ & $\mathrm{c}$ & $42,416.67$ & $\mathrm{~b}$ & 100.00 & $\mathrm{a}$ \\
\hline three & $49,415.00$ & $\mathrm{~b}$ & $109,786.20$ & $\mathrm{~b}$ & $44,748.33$ & $\mathrm{~b}$ & 93.15 & $\mathrm{~b}$ \\
\hline Four & $59,258.33$ & $\mathrm{a}$ & $128,242.77$ & $\mathrm{a}$ & $52,996.67$ & $\mathrm{a}$ & 90.51 & $\mathrm{~b}$ \\
\hline Five & $53,451.67$ & $\mathrm{a}$ & $102,970.39$ & $\mathrm{~b}$ & $39,853.33$ & $\mathrm{~b}$ & 76.07 & $\mathrm{c}$ \\
\hline Six & $56,553.33$ & $\mathrm{a}$ & $121,403.46$ & $\mathrm{a}$ & $41,255.00$ & $\mathrm{~b}$ & 73.92 & $\mathrm{c}$ \\
\hline Average & $52,219.00$ & & $108,563.66$ & & $44,254,00$ & & 89.80 & \\
\hline CV (\%) & 9.65 & & 4.53 & & 6.36 & & 9.77 & \\
\hline
\end{tabular}

${ }^{1}$ Averages followed by the same letter in the vertical did not differ amongst themselves by the Scott Knott test with $5 \%$ probability. 2 and 3 Data transformed to $\mathrm{y}=\sqrt{\mathrm{x}}$ e $\mathrm{y}=\operatorname{arcsen}[\sqrt{ }(\mathrm{x} / 100)]$, respectively.

per plant, with a greater number of drains per plant observed. Compared with primary production, where the average weight was $2,009 \mathrm{~g}$, the standard of mini-cabbages in all the treatments was seen to be adequate for the interests of production of cabbages of a reduced size. In a similar manner, the average diameter of the heads of $20.9 \mathrm{~cm}$, obtained in the primary patch was much greater than the diameter of heads of mini-cabbage, which varied from $9.69 \mathrm{~cm}$ (with two sprouts per plant) up to $8.34 \mathrm{~cm}$ (with six sprouts per plant).

The firmness of the mini-cabbage heads, expressed by the index of compactness, is a parameter directly associated with transportability and 'saleability', expiry date and consumer preferences. All the treatments showed scores above 9.0, with no significant differences between them, which despite being below the average of 9.8 of the primary patch, are clearly adequate for the desired standard. Lower average values for indexes of compactness observed in the mini-cabbages, compared with the primary patch, can be associated with the smaller cultivation cycle, given that, with this reduction in the cycle one can infer that fewer leaves were put forth from the sprouts, affecting the firmness of the mini-cabbage heads.

\section{CONCLUSION}

The best treatment system for stem sprouts, aiming to produciemini-cabbage, is that with four sprouts per plant, since it allows greater productivity and number of commercial heads, together with a commercial standard of heads with an average weight, diameter and firmness adequate to the standards demanded by the customer.

Table 2 - Averages of the characteristics of weight, diameter and compactness of mini-cabbage heads. Domingo Martins, INCAPER, $2016 .{ }^{1}$

\begin{tabular}{|c|c|c|c|c|c|c|}
\hline \multirow{2}{*}{$\begin{array}{l}\text { Density of sprouts per plant } \\
\text { two }\end{array}$} & \multicolumn{2}{|c|}{ Average weight (g) } & \multicolumn{2}{|c|}{ Average diameter $(\mathrm{cm})$} & \multicolumn{2}{|c|}{ Compactness (score of $0-10$ ) } \\
\hline & 509.00 & $\mathrm{a}$ & 9.69 & $\mathrm{a}$ & 9.02 & $\mathrm{a}$ \\
\hline three & 408.35 & $\mathrm{~b}$ & 9.22 & $\mathrm{a}$ & 9.22 & $\mathrm{a}$ \\
\hline four & 414.34 & $\mathrm{~b}$ & 8.77 & $\mathrm{~b}$ & 9.57 & $\mathrm{a}$ \\
\hline five & 388.16 & $\mathrm{~b}$ & 8.68 & $\mathrm{~b}$ & 9.17 & $\mathrm{a}$ \\
\hline $\operatorname{six}$ & 341.13 & $\mathrm{c}$ & 8.34 & $\mathrm{~b}$ & 9.38 & $\mathrm{a}$ \\
\hline Average & 412.20 & & 8.94 & & 9.27 & \\
\hline $\mathrm{CV}(\%)$ & 8.51 & & 4.10 & & 5.99 & \\
\hline
\end{tabular}

${ }^{1}$ Averages followed by the same letter in the vertical did not differ between themselves by the Scott Knott test at $5 \%$ probability. 


\section{ACKNOWLEDGEMENTS}

To Fundação de Amparo à Pesquisa e Inovação do Espírito Santo (FAPES) for financial support. To Instituto Capixaba de Pesquisa, assistência Técanica e Extensão Rural (INCAPER) for providing financial and logistical support to this unpublished scientific study.

\section{REFERENCES}

AQUINO, L.A. et al. Effect of spacing and doses of nitrogen on the qualitative characteristics of the yield of cabbage. Horticultura Brasileira, v.23, p.100-104, 2005. Available from: < http://www. scielo.br/pdf/hb/v23n1/a21v23n1.pdf $>$. Accessed: Aug. 08, 2016.

BACHMANN, J. Specialty vegetables. National Center for Appropriate Technology Transfer for Rural Areas. Current Topic, v.161, p.1-8, 2002. Available from: < https://attra.ncat.org/attrapub/summaries/summary.php?pub=36>. Accessed: Sept. 05, 2016.

BEZERRA, F.T.C. et al. Comportamento vegetativo e produtividade de girassol em função do arranjo espacial das plantas. Revista Ciência Agronômica, v.45, p.335-343, 2014. Available from: <http://www. scielo.br/pdf/rca/v45n2/a15v45n2.pdf>. Accessed: July 20, 2016.

BON, H. de. Melhorando as técnicas para a produção periurbana de hortaliças no sudeste asiático. Revista de Agricultura Urbana, v.10, p.1-5, 2005. Available from: <http://www.ruaf.org/sites/ default/files/AU10sudeste.pdf $>$. Accessed: Nov. 24, 2014.

CAMPAGNOL, R. et al. Condução vertical e densidade de plantas de minimelancia em ambiente protegido. Horticultura Brasileira, v.34, p.137-143, 2016. Available from: <http://www.scielo.br/pdf/ hb/v34n1/1806-9991-hb-34-01-00137.pdf>. Accessed: Sept. 06, 2016. doi: 10.1590/S0102-053620160000100021.

CARVALHO, E.V. de et al. Densidade de plantio em duas cultivares de mamona no sul do Tocantins. Revista Ciência Agronômica, v.41, n.3, p.387-392, 2010. Available from: <http://www.scielo. br/pdf/rca/v41n3/v41n3a10.pdf $>$. Accessed: Sept. 06, 2016. doi: 10.1590/S1806-66902010000300010.

CEASA-ES (CENTRAIS DE ABASTECIMENTO DO ESPÍRITO SANTO). Preço médio: produto/variedade, 2014. Available from: <http://www.ceasa.es.gov.br>. Accessed: Dec. 04, 2014.

COOLONG, T. Baby vegetables. University of Kentucky CCD Home CCD Crop Profiles College of Agriculture, Food and Environment, 2013. 3p. Available from: $<$ http://www.uky.edu/Ag/ CCD/introsheets/babyveggies.pdf $>$. Accessed: Feb. 08, 2015.
ECHER, M.M. et al. Características produtivas e qualitativas de mini abóbora em dois sistemas de cultivo. Horticultura Brasileira, v.32, n.3, p.286-291, 2014. Available from: <http:/www.scielo.br/ $\mathrm{pdf} / \mathrm{hb} / \mathrm{v} 32 \mathrm{n3} / 0102-0536-\mathrm{hb}-32-03-00286 . \mathrm{pdf}>$. Accessed: Aug. 23, 2016. doi: 10.1590/S0102-0536201400300008.

EMBRAPA (EMPRESA BRASILEIRA DE PESQUISA AGROPECUÁRIA). Manual de métodos de análise de solo. 2.ed. Rio de Janeiro: Ministério da Agricultura e do Abastecimento, 1997. 212p. (Documentos, 1).

FERREIRA, N.C. et al. Production and quality of inflorescences cauliflower a function of density. Revista de Agricultura Neotropical, v.1, n.2, p.1-7, 2014. Available from: <https:// periodicosonline.uems.br/index.php/agrineo/article/view/241>. Accessed: Ago. 09, 2016.

FRACARO, F. et al. Agronomic behavior of cabbage cultivars and hybrids in the northeast region of Rio Grande do Sul, Brazil. Ciência Rural, v.29, p.465-468, 1999. Available from: <http://www.scielo. br/pdf/cr/v29n3/a14v29n3.pdf $>$. Accessed: Aug. 20, 2016.

LOPES, W. de A.R. et al. Produtividade de cultivares de cenoura sob diferentes densidades de plantio. Revista Ceres, v.55, n.5, p.482487, 2008. Available from: <http://www.ceres.ufv.br/ojs/index.php/ ceres/article/view/3358/1250>. Accessed: Sept. 06, 2016.

ROSARO, S. Spring mix: an emerging crop for Florida. Florida: University of Florida, 2013. 2p. (Document SL-323).

SABIO, R.P. et al. Mini e "baby" frutas e hortaliças. Hortifruti Brasil, v.11, n.120, p.8-20, 2013.

SILVA, G.S. da et al. Espaçamentos entrelinhas e entre plantas no crescimento e na produção de repolho roxo. Revista Bragantia, v.70, n.3, p.538-543, 2011. Available from: <http://www.scielo.br/ pdf/brag/v70n3/a08v70n3.pdf>. Accessed: Sept. 09, 2016.

TAIZ, L.; ZEIGER, E. Fisiologia e desenvolvimento vegetal. 6.ed. Porto Alegre: Artmed, 2017. 888p.

TAKAHASHI, K.; CARDOSO, A.I.I. Plant density in production of mini lettuce cultivars in organic system management. Horticultura Brasileira, v.32, n.2, p.342-347, 2014. Available from: $<$ http://www. scielo.br/pdf/hb/v32n3/0102-0536-hb-32-03-00342.pdf >. Accessed: Sept. 13, 2016. doi: 10.1590/S0102-05362014000300017.

YEOMANS, J.C.; BREMNER, J.M. A rapid and precise method for routine determination of organic carbon in soil. Communications in Soil Science and Plant Analysis, v.19, n.13, p.1467-1476, 1988 . 